\title{
Omani Students Involvement in Evaluating Their Pharmacy Program
}

Ahmed A. Abusham* and Nawras A Al-Harthy

School of Pharmacy, College of pharmacy and Nursing, University of Nizwa, PC 616, PO Box 33, Nizwa, Oman

Abstract

Objectives: Research findings have showed that student satisfaction rate with their programs can be a reliable and valid indicator of effective teaching/learning. Hence, the objective of this study is to get our Arabic-speaking students involved in evaluating their existing English-taught Pharmacy Program and to assess their levels of satisfaction toward such Program.

Method: The study was conducted during March-June, 2016 and included 96 students from the University of Nizwa (Oman), who were enrolled in the School of Pharmacy Program and studied at least one online course. Data collection included participants' demographics and 20 statements categorized under six assessment criteria. Four-Point-Modified-Likert-type items were used to assess the students' levels of satisfaction. Analyses were conducted using STATA $^{\circ}$ v13 with descriptive and inferential statistics such as means and standard deviations.

Results: Female students represented $85.4 \%$ of the participant. The majority of the participants $(55.2 \%)$ were between 20 and 23 years of age. Bachelor students were $82.3 \%$ compared to Diploma students. The fifth and fourth-year students were $97.2 \%$ and $2.8 \%$ respectively. Satisfaction levels attainment in each of the assessment criteria was as follows: study plan and instructor $(68.7 \%)$ each, method of teaching (67.7\%), practicum and training courses $(51.0 \%)$, online courses $(38.5 \%)$, and students' satisfaction with the overall Pharmacy Program (67.7\%).

Conclusion: Participants showed intermediate levels of satisfaction toward the overall Pharmacy Program. However, there is a clear dissatisfaction with the online courses of the program.

\section{Key Message}

Our study addressed the fact that language could be a barrier for non-English speaking students in their learning process. This fact was clearly reflected in the results of the study as students were dissatisfied with their online courses compared with didactic lecture courses. Unlike online courses, in didactic lecture courses the instructor usually explains difficult English words and terminologies and this makes Arab students prefer regular courses to online courses. This attitude is mainly attributed to the ability of these students to match better between thinking, understanding and speaking using their mother language.

\section{Introduction}

The Pharmacists' professional roles and responsibilities have evolved historically from a focus on medication compounding and dispensing to extended pharmaceutical care services [1].

Nowadays their roles vary in different parts of the world. Examples are: community service, industry, research, academia, quality control and finally, the clinical service. This concept took turn in 1990 based on the introduction of the term "pharmaceutical care" by the researchers Hepler and Strand [2]. In addition, it is widely believed that pharmacists can make great contributions to the primary provision of health care ensuring the safe and effective use of medications [1]. As a result, the Universities and colleges, worldwide, responded by re-engineering their education system in an attempt to improve the quality of their undergraduates to best meet the needs of society [3].

Now there is a global attitude on the improvement of teaching methods in Pharmacy Colleges to produce better-qualified undergraduate [4]. This has equally been given much attention by our faculty and administration at the School of Pharmacy, College of Pharmacy and Nursing, University of Nizwa.

\section{Publication History:}

Received: February 24, 2018

Accepted: April 26, 2018

Published: April 28, 2018

Keywords:

Pharmacy Program, Satisfaction, Students, Oman behavior, is highly related to obtaining of satisfaction by the learner [5]. Most institutions of higher education have carried out a variety of research projects with an increased concern being placed upon the phenomena of student satisfaction [6]. The issue on student satisfaction in higher institutions of learning has gained popularity in recent years and research findings have established that student ratings can be a reliable and valid indicator of effective teaching $[5,7,8]$. Despite of this, faculty debate exists regarding the validity and reliability of student evaluations $[9,10]$.

Nevertheless, the opinion and feedback of Pharmacy students as the recipients of the program are important parameters to assessing the quality and the efficacy of our Pharmacy Program. Hence, the objective of this study is to assess the levels of Omani student's satisfaction toward the existing Pharmacy Program at University of Nizwa.

\section{Methods}

\section{Study design and participants}

The study was conducted during March-June, 2016 and included students from School of Pharmacy, University of Nizwa, the only University based School-of-Pharmacy in Oman. The school was established in the year 2004. The study included only the "Corresponding Author: Dr. Ahmed A. Abusham, School of Pharmacy, College of pharmacy and Nursing, University of Nizwa, PC 616, PO Box 33, Nizwa, Oman, E-mail: abusham@unizwa.edu.om

Citation: Abusham AA, Al-Harthy NA (2018) Omani Students Involvement in Evaluating Their Pharmacy Program. Int J Clin Pharmacol Pharmacother 3: 136. doi: https://doi.org/10.15344/2456-3501/2018/136

Copyright: (c) 2018 Abusham et al. This is an open-access article distributed under the terms of the Creative Commons Attribution License, which permits unrestricted use, distribution, and reproduction in any medium, provided the original author and source are credited. 
Citation: Abusham AA, Al-Harthy NA (2018) Omani Students Involvement in Evaluating Their Pharmacy Program. Int J Clin Pharmacol Pharmacother 3: 136. doi: https://doi.org/10.15344/2456-3501/2018/136

Page 2 of 5

\begin{tabular}{|l|l|l|l|}
\hline Student Status & Pharmacy Program & Total Credit Hours & $\begin{array}{l}\text { Expected Studying Years (15 Credit Hour } \\
\text { per Fall / Spring Semester) }\end{array}$ \\
\hline Regular student & $\begin{array}{l}\text { D Pharm: } \\
\text { Diplomain Pharmacy }\end{array}$ & 96 & 4 to 4.5 years \\
\cline { 2 - 4 } & $\begin{array}{l}\text { B Pharm: } \\
\text { BachelorinPharmacy }\end{array}$ & 149 & 5.5 to 6 years \\
\hline Bridging student & $\begin{array}{l}\text { Bridging: } \\
\text { Upgrading from Diploma to Bachelor in Pharmacy }\end{array}$ & 99 & 3 to 3.5 years \\
\hline
\end{tabular}

Table 1: Student Status as per the School of Pharmacy Programs.

Pharmacy students who attended, at least one online course $(\mathrm{N}=96)$. Demographic data of the participants were student's age, gender, years spent in the School of Pharmacy and the student status, either regular student (who is enrolled in Diploma (D Pharm)/Bachelor (B Pharm) program), or bridging student (who is upgrading from Diploma to Bachelor) (Table 1)

\section{Survey instrument}

The survey instrument was a self-administered questionnaire generated in consultation with the literature as well as with anecdotal information acquired from faculty members and students. In addition to participants' demographics, the questionnaire consisted of six criteria for the assessment of Pharmacy Program, including study plan, instructor, methods of teaching, practicum/training, online courses and finally, a general question was added to assess students' levels of satisfaction with the overall Pharmacy Program. Each of these assessment criteria provides four statements except the study plan (provides three statements) and the overall Pharmacy Program (provides only one statement).

We did a pilot study including 14 students (8 from class 4 and 6 from class 5) who represent all students' statuses and attended, at least, one online course. Thereafter, changes were made to improve the assessment statements. The project was reviewed and approved by the University of Nizwa research and ethics committee.

\section{Data analysis}

The collected demographic data of the participants and the six items of the Pharmacy Program were assessed using a four-point- modifiedLikert tool: strongly satisfied (1), satisfied (2), unsatisfied (3) and strongly unsatisfied (4). Analyses were conducted using STATA ${ }^{\oplus}$ v13 (2013) [11] with descriptive and inferential statistics such as means and standard deviations.

\section{Results}

Data analysis revealed that the number of female participants was greater than the number of males, representing $85.4 \%$. Age ranged from 20 to 29 and the majority of the participants' ages were in the range of 20-23 (55.2\%). The number of B Pharm students was greater than the number of D Pharm students, representing $82.3 \%$. The fifth and fourth year Students were $97.2 \%$ and $20.8 \%$ of the participants respectively. Most of students were regular $(87.5 \%)$, the reset were bridging students, those who joined the University to upgrade their status from D Pharm to B pharm (Table 2).

Table 3 lists the 20 statements that elicit the student's level of satisfaction. These statements represented the six aspects/items of

\begin{tabular}{|l|c|}
\hline Description & $\mathrm{n}(\%)$ \\
\hline Gender: & $14(14.6)$ \\
\hline Male & $82(85.4)$ \\
\hline Female & $53(55.2)$ \\
\hline Age (year): & $38(39.6)$ \\
\hline $20-23$ & $5(5.2)$ \\
\hline $24-27$ & $79(82.3)$ \\
\hline$>27$ & $17(17.7)$ \\
\hline Study program: & \\
\hline Bachelor (BPharm) & $84(87.5)$ \\
\hline Diploma (DPharm) & $12(12.5)$ \\
\hline Student status: & \\
\hline Regular & $20(20.8)$ \\
\hline Bridging & $76.2)$ \\
\hline Class & \\
\hline 4th year & \\
\hline 5 th year & \\
\hline Thle $:$ Demogra & \\
\hline
\end{tabular}

Table 2: Demographic Characteristics of the participants $(\mathrm{N}=96)$.

the Pharmacy Program including study plan, instructors, methods of teaching, practicum courses/training, online courses and finally, the overall Pharmacy Program at University of Nizwa. The responses to these statements constitute the dependent variable of the study. Figure 1 illustrates the percentages of students' satisfaction with each assessment item.

Table 3 shows the attainment of satisfaction levels with numbers, percentages, mean and standard deviations followed by the overall satisfaction levels for each evaluation statement. The level of satisfaction with the Pharmacy Program study plan was 68.7\%. Satisfaction was positive towards the prerequisites arrangement $(\mathrm{M} \pm \mathrm{SD}=2.3 \pm 0.79)$, and the easiness of following the study plan $(\mathrm{M} \pm \mathrm{SD}=2.3 \pm 0.74)$.

Students were satisfied with instructor teaching and assessment in a similar manner (68.7\%). Student appeared to be more satisfied with the instructor's teaching material that enhances their knowledge and skills, $(\mathrm{M} \pm \mathrm{SD}=2.2 \pm 0.72)$.

Regarding the method of teaching, the overall satisfaction was $67.7 \%$. Lectures were presented in understandable manner $(\mathrm{M} \pm \mathrm{SD}=$ $2.3 \pm 0.82$ ), and there is full integration between lectures and laboratory sessions $(\mathrm{M} \pm \mathrm{SD}=2.3 \pm 0.82)$. 
Citation: Abusham AA, Al-Harthy NA (2018) Omani Students Involvement in Evaluating Their Pharmacy Program. Int J Clin Pharmacol Pharmacother 3: 136. doi: https://doi.org/10.15344/2456-3501/2018/136

Page 3 of 5

\begin{tabular}{|c|c|c|c|c|c|c|c|}
\hline SN & Statements & $\begin{array}{l}\text { Strongly } \\
\text { agree (1) } \\
\mathrm{n}(\%)\end{array}$ & $\begin{array}{l}\text { Agree } \\
(2) \mathrm{n} \\
(\%)\end{array}$ & $\begin{array}{l}\text { Disagree } \\
(3) \mathrm{n} \\
(\%)\end{array}$ & $\begin{array}{l}\text { Strongly } \\
\text { disagree } \\
(4) n(\%)\end{array}$ & $\begin{array}{l}{ }^{*} \text { Mean } \pm \\
\text { standard } \\
\text { deviation }\end{array}$ & $\begin{array}{l}\text { Overall } \\
\text { satisfactio } \\
\mathrm{n} \mathrm{n}(\%)\end{array}$ \\
\hline \multicolumn{8}{|c|}{ Study plan: } \\
\hline 1 & Study plan provides good guidance to select subjects & $10(10.4)$ & $59(61.5)$ & $21(21.8)$ & $6(6.3)$ & $2.3 \pm 0.78$ & \multirow[t]{3}{*}{$66(68.7)$} \\
\hline 2 & Sequence of prerequisites arrangement is acceptable & $13(13.5)$ & $45(46.9)$ & $35(36.5)$ & $3(3.1)$ & $2.3 \pm 0.79$ & \\
\hline 3 & Study plan is easy to follow & $12(12.5)$ & $51(53.1)$ & $26(27.1)$ & $7(7.3)$ & $2.3 \pm 0.74$ & \\
\hline \multicolumn{8}{|c|}{ Instructors: } \\
\hline 1 & I find instructors teaching style attractive & $6(6.3)$ & $63(65.6)$ & $19(19.7)$ & $8(8.4)$ & $2.3 \pm 0.71$ & \multirow[t]{4}{*}{$66(68.7)$} \\
\hline 2 & $\begin{array}{l}\text { Instructors' teaching material enhances the student knowledge and } \\
\text { skills }\end{array}$ & $10(10.4)$ & $59(61.5)$ & $21(21.8)$ & $6(6.3)$ & $2.2 \pm 0.72$ & \\
\hline 3 & Instructors always assess the progress in student performance. & $5(5.2)$ & $56(58.3)$ & $24(25.0)$ & $11(11.5)$ & $2.4 \pm 0.76$ & \\
\hline 4 & Instructor simplifies the material in a way I can understand it.. & $12(12.5)$ & $51(53.1)$ & $26(27.1)$ & $7(7.3)$ & $2.4 \pm 0.76$ & \\
\hline \multicolumn{8}{|c|}{ Methods of teaching: } \\
\hline 1 & Learning material is presented in an understandable manner & $9(9.4)$ & $57(59.4)$ & $16(16.6)$ & $14(14.6)$ & $2.4 \pm 0.85$ & \multirow[t]{4}{*}{$65(67.7)$} \\
\hline 2 & It is possible to clarify unclear points during the lecture & $14(14.6)$ & $46(47.9)$ & $28(29.2)$ & $8(8.3)$ & $2.3 \pm 0.82$ & \\
\hline 3 & Lectures and laboratory sessions are fully integrated. & $11(11.5)$ & $56(58.3)$ & $18(18.7)$ & $11(11.5)$ & $2.3 \pm 0.82$ & \\
\hline 4 & We are applying problem solving based teaching. & $8(8.3)$ & $53(55.2)$ & $24(25.0)$ & $11(11.5)$ & $2.4 \pm 0.80$ & \\
\hline \multicolumn{8}{|c|}{ Practicum courses and training: } \\
\hline 1 & Training period is sufficient to acquire necessary skills. & $17(17.7)$ & $39(40.6)$ & $28(29)$ & $12(12.5)$ & $2.3 \pm 0.80$ & \multirow[t]{4}{*}{$49(51.0)$} \\
\hline 2 & Training logbook is based on course objectives & $10(10.4)$ & $34(35.4)$ & $37(38.6)$ & $15(15.6)$ & $2.3 \pm 0.76$ & \\
\hline 3 & $\begin{array}{l}\text { Logistics (transportation and accommodation) are arranged in } \\
\text { advance. }\end{array}$ & $7(7.3)$ & $38(39.6)$ & $34(35.4)$ & $17(17.7)$ & $2.4 \pm 0.79$ & \\
\hline 4 & Theory and practice during practicum courses are fully integrated. & $9(9.4)$ & $41(42.7)$ & $37(38.5)$ & $9(9.4)$ & $2.5 \pm 0.83$ & \\
\hline \multicolumn{8}{|c|}{ Online courses: } \\
\hline 1 & Online courses are as informative as regular classes. & $4(4.2)$ & $27(28.1)$ & $37(38.5)$ & $28(29.2)$ & $2.9 \pm 0.86$ & \multirow[t]{4}{*}{$37(38.5)$} \\
\hline 2 & Online discussion covers all content of the subject.. & $7(7.3)$ & $21(21.9)$ & $40(41.6)$ & $28(29.2)$ & $2.9 \pm 0.89$ & \\
\hline 3 & There is enough time to participate in online discussion. & $14(14.6)$ & $41(42.7)$ & $24(25.0)$ & $17(17.7)$ & $2.5+0.95$ & \\
\hline 4 & Online course discussion motivates me to read more. & $8(8.3)$ & $25(26.0)$ & $45(46.9)$ & $18(18.8)$ & $2.8 \pm 0.86$ & \\
\hline \multicolumn{8}{|c|}{ Satisfaction with the overall Pharmacy Program at University of Nizwa } \\
\hline 1 & $\begin{array}{l}\text { Overall, I am satisfied with the Pharmacy Program at University of } \\
\text { Nizwa }\end{array}$ & $8(8.3)$ & $57(59.4)$ & $26(27.1)$ & $5(5.2)$ & $2.3 \pm 0.69$ & $65(67.7)$ \\
\hline
\end{tabular}

Table 3: Attainment of satisfaction levels with numbers, percentages, mean and standard deviations followed by the overall satisfaction levels for each evaluation statement. $(\mathrm{N}=96)$.

${ }^{*}$ Mean \pm standard deviations $(\mathrm{M} \pm \mathrm{SD})$ are representing satisfaction levels $1-4 ; 1=$ strongly agree, $2=$ agree. $3=$ disagree, $4=$ strongly disagree.

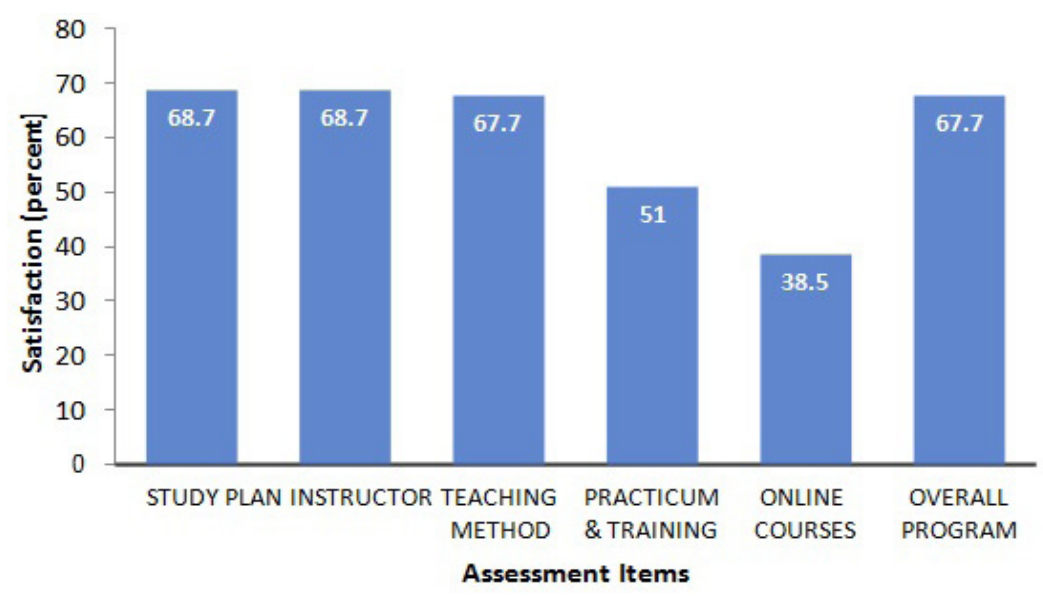

Figure 1: Percentage of students' satisfaction with each assessment item. 
With practicum and training courses, the overall satisfaction level was $51.0 \%$. The lack of synchronization between theory and practice during practicum courses represented the most dissatisfying element, $(\mathrm{M} \pm \mathrm{SD}=2.5 \pm 0.83)$, followed by the insufficiency in the arrangement of course logistics like transportation and/or accommodation facilities, $(\mathrm{M} \pm \mathrm{SD}=2.4 \pm 0.79)$ Study results showed a clear dissatisfaction with the online courses. The reported average satisfaction level was $38.5 \%$. Results revealed that online courses were not as informative as regular courses $(\mathrm{M} \pm \mathrm{SD}=2.9 \pm 0.86)$, online courses do not cover all contents of the subject $(\mathrm{M} \pm \mathrm{SD}=2.9 \pm 0.89)$, there is not sufficient time to interact with the instructor $(\mathrm{M} \pm \mathrm{SD}=2.5 \pm 0.95)$, and the online course discussion does not motivate students to read more $(\mathrm{M} \pm \mathrm{SD}$ $=2.8 \pm 0.86$ ).

Finally, students reported their satisfaction level with the overall Pharmacy Program at University of Nizwa as $67.7 \%(\mathrm{M} \pm \mathrm{SD}=$ $2.3 \pm 0.69$ ) (Table 3 ).

The purpose of this study was to evaluate students' levels of satisfaction with the Pharmacy- program at University of Nizwa. In this study, we assessed the learner- perceived levels of compliance with his/her desires or demands towards the existing Pharmacy Program. While promoting the quality in Pharmacy Programs, higher education institutions consider student satisfaction as one of the major principles in higher education; the higher the service quality, the more satisfied the student [12]. Accordingly, satisfaction is based on customer expectations and perception of service quality. Consequently, institutions have been paying more attention to meeting the expectations and needs of their students $[9,13]$. Therefore, this study assessed the satisfaction levels of students with a number of elements contributing to the existing Pharmacy- program at University of Nizwa.

The Students' level of the satisfaction with the Pharmacy Program study plan was $68.7 \%$. Students showed high level of satisfaction with the way study plan guides them to register for each semester $(\mathrm{M} \pm \mathrm{SD}=$ $2.3 \pm 0.78$ ); and with the clearly-stated pre-requisites and co-requisites for each course $(\mathrm{M} \pm \mathrm{SD}=2.3 \pm 0.79)$. This result is in-line with another study assessing students' academic satisfaction conducted in King Fahd University of Petroleum and Minerals, Dhahran, Saudi Arabia where satisfaction levels with the curriculum study plan was $84 \%$ [14]. Arbaugh highlighted the importance of the convenience and flexibility of any educational program study plan as an important contributor to student satisfaction [15].

Our students were satisfied with the instructor in a similar manner $(68.7 \%)$ and in this aspect they were more satisfied with the Instructors interaction style that enhances the student knowledge and skills, $(\mathrm{M} \pm \mathrm{SD}=2.2 \pm 0.72)$. A 9-year-period study by Tessema et al. [5], in Midwestern United States University, focused on the evidence of factors affecting college students' satisfaction with major curriculum. The findings of this study showed that quality of instruction is one of the statistically significant impacts on student satisfaction. Some authors believe that both quality and quantity of interaction is crucial for student satisfaction [16]. Majority of researchers believe that student ratings are useful means of evaluating teaching $[5,7,8]$. However, some educators and researchers continue to believe that student ratings of teachers are bad tools for assessing teaching effectiveness $[9,10]$.

Regarding the method of teaching, the overall satisfaction was $67.7 \%$. Sixty-three percent of the students agreed there was a full integration between lectures and laboratory sessions Int J Clin Pharmacol Pharmacother ISSN: 2456-3501
$(\mathrm{M} \pm \mathrm{SD}=2.3 \pm 0.82)$. Students $(68.8 \%)$ also agreed that the lectures were presented in understandable manner. Although most of our students are Arabic speaking, the level of satisfaction toward the statement "Learning material is presented in an understandable manner" was positive. This could be attributed to the huge effort by the instructors to troubleshoot the communication problem among the students as $62.8 \%$ of the students agreed that they can clarify unclear issues during the lecture $(\mathrm{M} \pm \mathrm{SD}=2.3 \pm 0.82)$. As the teaching language in our University is English, language appeared to be a troublesome that influence communication between students and tutors.

Language barriers and cultural differences are affecting many of our students because they feel embarrassed when they speak in English in-front-of others. This problem is common especially within group work [17].

The overall satisfaction level with practicum and training courses was $51.0 \%$. The lack of synchronization between theory and practice during practicum courses represented the most dissatisfying element, $(\mathrm{M} \pm \mathrm{SD}=2.5 \pm 0.83)$, followed by the insufficiency in the arrangement of course logistics like transportation and/or accommodation facilities, $(\mathrm{M} \pm \mathrm{SD}=2.4 \pm 0.79)$.

Although the students were satisfied with the training period and its usefulness, they were not quite satisfied with the integrity of what is studied and what is practiced. In a similar study conducted in the University of Jordan, the satisfaction level of students with their practicum experience was $49 \%$. Students' concerns emphasized issues like connections between university courses and practicum requirements, field sites and supervision [18].

One notable important finding in our study was the student satisfaction level with the online courses, which was $38.5 \%$. Students' responses reflected that online courses were not as informative as regular courses $(\mathrm{M} \pm \mathrm{SD}=2.9 \pm 0.86)$; online courses do not cover all content of the subject $(\mathrm{M} \pm \mathrm{SD}=2.9 \pm 0.89)$; there is not sufficient time to interact with the instructor $(\mathrm{M} \pm \mathrm{SD}=2.5 \pm 0.95)$; and online course discussion does not motivate students to read more $(\mathrm{M} \pm \mathrm{SD}$ $=2.8 \pm 0.86$ ).

A meta-analysis about studies of comparison between online education and traditional methods showed that students find online education as satisfactory as traditional classroom [19]. Another study by Sikora showed that $70 \%$ of students enrolled in undergraduate courses reported that they were satisfied with their online course experiences than with their traditional classroom experiences [20].

In our study, the students' satisfaction with online learning was generally negative (table 1). Unlike online course, in didactic lectures the instructor usually explains difficult English words and terminologies. This, among other factors, makes students prefer regular courses to online courses. All our students have to take International English Language Testing System (IELTS) or Test of English as a Foreign Language (TOEFL) before being admitted to the University.

Nevertheless Language could still be a barrier for non-Englishspeaking students when they start a course. Some researchers argue that different language systems may cause difficulty for non- Englishspeaking students to understand English language, particularly when they move with their learning abilities from first language to the second language [21]. 
Citation: Abusham AA, Al-Harthy NA (2018) Omani Students Involvement in Evaluating Their Pharmacy Program. Int J Clin Pharmacol Pharmacother 3: 136. doi: https://doi.org/10.15344/2456-3501/2018/136

Page 5 of 5

The last statement in this study was to assess the students satisfaction level with the overall Pharmacy Program at University of Nizwa. Results revealed a satisfaction level of $67.7 \%(\mathrm{M} \pm \mathrm{SD}=$ $2.3 \pm 0.69)$. This result is chary compared to similar study conducted at the Midway School of Pharmacyin Chatham, Kent, UK, as their students' satisfaction with their Pharmacy- program showed a percentage of $97 \%$ giving them the most satisfied result compared with any other higher education institution in the UK [22].

\section{Limitations of the Study}

The sample size in this study is relatively small; however, it represents most of the students who have been exposed to all aspects of the assessment in this study. Also, the assessment aspects or items used in the study may not represent all the required evaluative instruments for such an educational program.

\section{Conclusion and Recommendations}

We conclude that it is a complicated issue to assess Arabic-speaking students' satisfaction toward their English-taught Pharmacy Program.

In this study, participants showed an intermediate level of satisfaction towards the overall Pharmacy Program. However, there is a clear dissatisfaction with the online courses of the program. This could be attributed to the differences in languages (Arabic vs English). Further research will likely generate additional insights of learners and instructors about when, and how to apply online courses.

\section{Competing Interests}

The authors declare that they have no competing interests.

\section{References}

1. WHO (2006) New tool to enhance role of pharmacists in health care.

2. Hepler C, Strand L (1990) Opportunities and responsibilities in pharmaceutical care. JHosp Pharm 47: 533-543.

3. Anderson S (2002) The state of the world's Pharmacy: a portrait of the Pharmacy profession. Journal of interprofessional care 16: 391-404.

4. Klemenčič M, Chirikov I (2015) How Do We Know How Students Experience Higher Education? On the Use of Student Surveys. In The European Higher Education Area.

5. Tessema MT, Ready K, Yu W (2012) Factors affecting college students' satisfaction with major curriculum: Evidence from nine years of data. International Journal of Humanities and Social Science 2: 34-44.

6. Clayson DE (2009) Student evaluations of teaching: Are they related to what students learn? A meta-analysis and review of the literature. Journal of Marketing Education 31: 16-30.

7. Darwin S (2016) The emergence of contesting motives for student feedback-based evaluation in Australian higher education. Higher Education Research \& Development. 35: 419-432.

8. Alderman L, Towers S, Bannah S (2012) Student feedback systems in higher education:A focused literature review and environmental scan. Quality in Higher Education 18: 261-280.

9. Penny AR (2003) Changing the agenda for research into students' views about university teaching: Four shortcomings of SRT research. Teaching in higher education 8: 399-411.

10. Sproule R (2000) Student Evaluation of Teaching: Methodological Critique. Education policy analysis archives.

11. Stata Corp LP (2013) Stata Statistical Software Release 13. STATA Statacorp LP, 4905 Lakeway Drive, Texas.USA.
12. Kasule GW, Wesselink R, Noroozi O, Mulder M (2015) The current status of teaching staff innovation competence in Ugandan universities: perceptions of managers, teachers, and students. Journal of Higher Education Policy and Management. 37: 330-343.

13. Devlin M, Samarawickrema G (2010) The criteria of effective teaching in a changing higher education context. Higher Education Research \& Development 29: 111- 124.

14. Aldosary AS (1999) Students' academic satisfaction: the case of CED at KFUPM. Engineering Sciences 11: 99-107.

15. Arbaugh JB (2000) How classroom environment and student engagement affect learning in Internet-based MBA courses. Business Communication Quarterly 63: 9-26.

16. Michael GM, Kearsley G (2011) Distance education: A systems view of online learning. Cengage Learning.

17. Kember D (2000) Misconceptions about the learning approaches, motivation and study practices of Asian students. Higher education 40: 99121.

18. Jabery AL, Mohammad A, Khamra AL, Hatem A (2013) Special Education Practicum at The University of Jordan: Preliminary Indicators of Students' Satisfaction and Concerns. International Journal of Special Education 28: 101-110.

19. Allen M, Bourhis J, Burrell N, Mabry E (2002) Comparing student satisfaction with distance education to traditional classrooms in higher education: A meta-analysis. The American Journal of Distance Education 16: 83-97.

20. Sikora AC, Carroll CD (2002) A Profile of Participation in Distance Education: 1999-2000. Postsecondary Education Descriptive Analysis Reports. Washington: National Center for Education Statistics.

21. McGee A, Lawrence A (2009) Teacher educators inquiring into their own practice. Professional Development in Education 35: 139-157.

22. The Pharmaceutical Journal (2009) Pharmacy school comes out top in higher education survey of student satisfaction. The Pharmaceutical Journal 283: 202 